\title{
Perspective of Women in the Nepalese Economy: Opportunities, Challenges and Future Scope
}

\author{
Rashmee Shilpakar Rajkarnikar ${ }^{9}$
}

\begin{abstract}
Bidirectional relationship between economic development and women's empowerment is one of the issues in this relationship. Economic growth and prosperity is necessary to improve gender inequality by reducing poverty. Another argument assumes that women could play a fundamental role in development. Thus, equality is valuable. Capacity of women is crucial for changing their live positively. This paper explores the scopes, and opportunities provided by the government policies for Nepalese women and analyzed the constraints in implementing the policies based on this authors' two previous studies -- Effectiveness of Gender Responsive Budgeting in Nepal, 2019; and Women's Contribution in Family Economy in Nepal, 2010. Although more than NRs 500 billion of budget is allocated in the programs directly benefitting women, results are not observed as expected. Sustainable economic development is possible only if the women are capable to utilize the resources; capable to control and reap the benefits of economic opportunities; and capable to make strategic decision for changing their lives positively, once they have access to the resources. Once women are capable, there would be no limitation to be involved in economics. Result Based Budgeting (RBB) systems has proven to be a compatible framework for the institutionalization of gender budgeting.
\end{abstract}

Keywords: Nepali women in economics, Gender responsive budget, Family economy, Opportunities, Challenges.

\section{Introduction}

Most people believe that there should be economic equality between men and women for economic growth. Kofi Annan, The Secretary General of the United Nations, has argued that achieving gender equality is a 'prerequisite' to achieving the Millennium Development Goals (MDGs), including eliminating poverty (United Nations, 2005). Here, the concept of gender equality is used as a yardstick to gauge the impact of development. This advocates that development would not be possible without women empowerment. Women's empowerment is defined as improving the ability of women to access the elements of development-particular in health, education, earning opportunities, rights, and political participation. The relationship between women and economic development is a complex issue. Bidirectional relationship between economic development and women's empowerment is one of the issues in this relationship. The first argument focuses on creating the conditions for economic growth and

9 Dr. Rajkarnikar is an Assistant Professor in Central Department of Economics, Tribhuvan University. rashmi.rajkarnikar@cdec.tu.edu.np.

This paper is based on presentation as a Guest Speaker in the Women in Nepali Economic Growth Conference on 'Future Scope of Women in Nepali Economics'. 
prosperity to improve gender inequality by reducing poverty. It assumes that when poverty is reduced, the condition of everyone including women is improved. Another argument assumes that women could play a fundamental role in development. Women are currently worse-off than men, and this inequality between genders is repulsive in its own right. Thus, equality is valuable. The gender gap in education, political participation, and employment opportunities should therefore be reduced not only because it is equitable to do so, but also because it will have beneficial consequences on many other society-wide outcomes (Duflo, 2012).

Economic growth has meant that most citizens live better along almost every dimension of material life. Technology and capital intensity are two major initial conditions contributing growth. It is assumed that better technology leads to a higher level of labor efficiency. An economy in which the efficiency of labor is higher will be a richer and a more productive economy. Determinants of capital intensity are 'investment effort' being made in the economy, and the 'investment requirements' of the economy. The ratio between the investment effort and the investment requirements of the economy determines the economy's capital intensity.

Economic policies -- the good and the bad policies -- on the other hand accelerate or retard long-run economic growth. Argentines were richer than Swedes in the years back before World War - I began in 1914, but Swedes today have perhaps four times the material standard of living and the economic productivity level of Argentines. Almost all of this difference is due to differences in growth policies--good policies in the case of Sweden, bad policies in the case of Argentina-for there were few important differences in initial conditions at the start of the twentieth century to give Sweden an edge (DeLong, 2002).

The women in economics are a prerequisite for sustainable development. Increasing the role of women in the economy is said to be the part of the solution to the financial and economic crises and critical for economic resilience and growth. However, following would be the conditions necessary for women to be in economics: i) access to resources and capacity to utilize it; ii) access to economic opportunities and control over the economic benefits of those opportunities; and iii) access to strategic choices leading to positive changes in their lives.

This paper explores the scope and opportunities for the women provided by the government policies to be in Nepalese women in economics. The paper also analyzed the constraints in implementing the policies with the help of two studies -- Effectiveness of Gender Responsive Budgeting in Nepal, 2019 (report submitted to University of Grant Commission (UGC), Research Division); and Women's Contribution in Family Economy in Nepal, 2010 (a thesis submitted to Central Department of Buddhist Studies as requirement under M.A. in Buddhist Studies). ${ }^{10}$

\section{Method}

Economic policies are reviewed for ascertaining opportunities for women in economics in Nepal. Challenges and scopes for women in Nepali economy are derived based on this authors' two previous studies i) Effectiveness of Gender Responsive Budgeting (GRB) in Nepal, 2019; and ii) Women's Contribution in Family Economy in Nepal, 2010.

In Nepal GRB aims at raising awareness of the gendered impacts of budget and to make governments accountable for ensuring gender equality and women's rights, especially among

\footnotetext{
${ }^{10}$ See the details of the two studies in the website $h t t p: / / w w w . d r$-rashmee.com
} 
the poor. Ministry of Finance (MoF) has introduced gender budgeting system in the fiscal year FY 2007/08 by allocating budget for direct benefit to the women. It has been observed in $14^{\text {th. }}$ Periodic Plan 2016 - 2019 that there remained significant gender inequalities and distribution of opportunities among women and men. This has clearly indicated that mere preparing gender responsive budgeting and strategies does not solve the problem of inequality. Therefore, translating gender mainstreaming into actual action requires re-examination of the policies, programs and planning/budgeting process from a gender perspective. This study examined the effectiveness of GRB implementation at federal level and local level (five municipalities of Kathmandu Valley). The effectiveness of GRB was measured using two sets of analytical tools: Integrated Organizational Model (IOM) and CAMELS rating. IOM was executed involving municipal staff in participatory assessment procedure. Evaluation matrix was developed based on the five indicators provisioned in the GRB Guideline, 2012 to identify the strengths and weakness of women development programs in municipalities. Assessment of gender sensitivity in GRB was done using 'CAMELS' ratings.

Similarly, economic activities - the production and sales of goods and services - are the most important and the primary activities, which hold the key to human happiness and fulfillment. To more extent, it is a means for livelihood. Indigenous occupations of members of the community / society are based on the skills either transformed by ancestor or skills acquire through the education. Due to huge migration and resulting competitive life style, machines and automation have considerably replaced method of doing indigenous economic activities. The study was conducted to explore the contribution of women in family economy in the community. Detailed workflow analysis of the 41 indigenous economic activities (production / services and its sales process) was conducted to identify the women's contribution in the family income. Besides, other elements of economics were also analyzed by interviewing more than 100 individuals (men and women) in Kathmandu, Lalitpur, and Bhaktapur districts.

\section{Results}

Ester Boserup was the first to lead the discussion on women in economics. She argued that development has had a negative impact on women and has marginalized them in economically developing societies (Boserup, 1970). Eventually, this idea of Boserup resulted in the conceptualization of a strategy for integrating women in development. Since then, there has been a substantial flow of resources and personnel through development agencies to achieve the objective of integrating women in development in the developing countries. The true nature of women in economics is one in which women's contribution among other has empowered them to have equal access to resources, technology, opportunity, decision making and control of income, ultimately, whether it has improved their quality of life.

Historically, Nepal has predominantly been a patriarchal society where women are generally subordinate to men. But, in the modern Nepalese society, roles of women have changed in various ways. Nepal has made various national and international gender equality and womencentric commitments through signing of conventions and treaties. As a response, MoF of Nepal has introduced 'Gender Budgeting System' in the fiscal year FY 2007/08. Similarly, 'Constitution of Nepal-2015 has guaranteed fundamental rights to all citizens without discrimination on the basis of ethnicity, caste, religion, or sex. Modernizing society along with reach of education to the general population itself has played an important role to promote 
gender equality. Consecutive periodic plans have addressed in incorporated gender issues in the national development plans.

\section{Conducive Environment for Women in Economy of Nepal}

Introduction of 'Gender Budgeting System' in 2007/08 has categorized national budget under three broad headings like budget directly benefiting women, indirectly benefiting women, and neutral budget. Budget allocated is considered directly benefitting women if, government funded programs are beneficial for more than 50 percent women (specifically in targeted expenditures by government departments and authorities to women or men in the community intended to meet their particular needs) (table 1). Government of Nepal allocated 38.65 percent of the total budget in the programs directly benefitting women for the fiscal year - 2020/21. Gender budgeting is a continuous process that must be applied to all levels and stages of the policy process and assumed to be a powerful tool that can reduce the vulnerability of women and girls and transform their situation which will subsequently decrease the poverty of women (GoI, 2015).

Table 1: Gender Responsive Budget Allocation, (2008 -2020)(in Rs. In billion)

\begin{tabular}{|c|c|c|c|c|c|}
\hline \multirow{2}{*}{ Fiscal Years } & \multicolumn{2}{|c|}{ Direct Responsive Budget } & \multirow{2}{*}{ Fiscal Years } & \multicolumn{2}{c|}{ Direct Responsive Budget } \\
\cline { 2 - 3 } & Amount & Percent & & Amount & Percent \\
\hline $2008 / 09$ & 19 & 11.3 & $2015 / 16$ & 136 & 21.93 \\
\hline $2009 / 10$ & 28 & 13.9 & $2016 / 17$ & 182 & 22.27 \\
\hline $2010 / 11$ & 49 & 17.3 & $2017 / 18$ & 242 & 23.1 \\
\hline $2011 / 12$ & 61 & 17.9 & $2018 / 19$ & 508 & 38.65 \\
\hline $2012 / 13$ & 73 & 19.05 & $2019 / 20$ & 585 & 38.17 \\
\hline $2013 / 14$ & 87 & 21.51 & $2020 / 21$ & 562 & 38.16 \\
\hline $2014 / 15$ & 112 & 21.75 & \multicolumn{3}{|c}{} \\
\cline { 5 - 6 }
\end{tabular}

Source: MoF, Budget speeches, 2008 - 2020

Gender Responsive Budget (GRB) Formulation Guideline, 2012 was issued by MoF with the objective of making national budget and programs more gender responsive; establishing relationship between program and budget for gender equality; measuring gender sensitivity of the budget objectively with the help of numerical scores; and evaluating the achievements of projects based on benefits received by the women or not. The GRB Guideline outlined the following five broad gender related indicators for gender sensitivity measurements and their weightage (Scores): Table 2.

Table 2: Gender Responsive Indicators

\begin{tabular}{|c|l|c|}
\hline S.N. & \multicolumn{1}{|c|}{ Indicators } & Scores in \% \\
\hline 1 & Women's Capacity Building & 20 \\
\hline 2 & $\begin{array}{l}\text { Women's Participation in formulation and implementation of } \\
\text { programmes }\end{array}$ & 20 \\
\hline 3 & Women's share in benefits. & 30 \\
\hline 4 & Support to employment and income generating activities for women. & 20 \\
\hline 5 & Quality reform in time used and minimization of women's workload. & 10 \\
\hline & \multicolumn{1}{|c|}{ Total } & $\mathbf{1 0 0}$ \\
\hline
\end{tabular}

Source: GRB Formulation Guideline, 2012. 
In order to avoid subjective orientation of the indicators the guideline has also outline subindicators for each of the indicators and defined every sub-indicator objectively. GRB Formulation Guideline could be considered a milestone in gender sensitive budgeting system in Nepal, which has put effort to clarify the ambiguity of what programs and activities are directly and indirectly benefitting women. The Constitution of Nepal -2015 has guaranteed women's rights in all spheres of their lives. Review of the constitution in gender perspective with general remarks is highlighted in the (table 3 ).

\section{Table 3: Review of Constitution of Nepal - 2015 in Gender Perspective}

\begin{tabular}{|c|c|c|}
\hline Content & $\begin{array}{l}\text { Provisions in the } \\
\text { Constitution }\end{array}$ & General Remarks \\
\hline Preamble & $\begin{array}{l}\text { Commitment to end } \\
\text { gender } \\
\text { discrimination }\end{array}$ & $\begin{array}{l}\text { - Failed to commit to substantive equality } \\
\text { - Failed to commit to end patriarchy; } \\
\text { - Women's contribution throughout democratic movement is } \\
\text { not recognized; } \\
\text { - Failed to incorporate the concept of equal citizenry }\end{array}$ \\
\hline \multicolumn{3}{|l|}{ Citizenship } \\
\hline $\begin{array}{l}\text { Part 2, Art } 11 \\
\text { Citizenship }\end{array}$ & $\begin{array}{l}\text { Father or Mother } \\
\text { provision on } \\
\text { citizenship by } \\
\text { descent }\end{array}$ & $\begin{array}{l}\text { Art } 11(5) \text { and (7) compromises the ability of women to } \\
\text { independently confer citizenship to her child as the father of } \\
\text { the child must be unidentified or to claim citizenship by } \\
\text { descent; in cases where a Nepali woman is married to a } \\
\text { foreigner, she may only confer naturalized (not descent) } \\
\text { citizenship }\end{array}$ \\
\hline $\begin{array}{l}\text { Part } 2 \text { Art } 11 \\
(6) \\
\text { Citizenship }\end{array}$ & $\begin{array}{l}\text { Men can confer } \\
\text { naturalized } \\
\text { citizenship to his } \\
\text { foreign national wife }\end{array}$ & $\begin{array}{l}\text { Art } 11(6) \text { is silent on conferring citizenship to foreign } \\
\text { husband, that means it is likely that foreign men who marry } \\
\text { Nepali citizen women, cannot get the citizenship on the } \\
\text { ground of marriage }\end{array}$ \\
\hline \multicolumn{3}{|c|}{ Key Fundamental Rights } \\
\hline \multirow[t]{2}{*}{$\begin{array}{l}\text { Article } 18 \\
\text { Right to } \\
\text { Equality }\end{array}$} & Non -discrimination & $\begin{array}{l}\text { - The prohibited grounds of discrimination are listed, but } \\
\text { discrimination is not defined } \\
\text { - Discrimination on the ground of Sex is prohibited but not } \\
\text { gender, gender-based traditions, rituals or customs }\end{array}$ \\
\hline & Right to equality & $\begin{array}{l}\text { - The equal rights of women in the political, economic and } \\
\text { social spheres are not recognized } \\
\text { - Right to equality has been limited to formal equality, no } \\
\text { provision on substantive equality } \\
\text { - Provision of gender equality, however according to Article } \\
55 \text { this provision cannot be enforced by courts and no } \\
\text { question may be raised in courts even when the State } \\
\text { objectives are not met }\end{array}$ \\
\hline $\begin{array}{l}\text { Article 31: } \\
\text { Right to } \\
\text { education }\end{array}$ & Right to education & Women's right to free higher education is not addressed. \\
\hline $\begin{array}{l}\text { Article } 20 \text { : } \\
\text { Right relating } \\
\text { to justice }\end{array}$ & $\begin{array}{l}\text { Right relating to } \\
\text { justice }\end{array}$ & $\begin{array}{l}\text { - right of free legal aid to indigent parties as stated in Sub } \\
\text { Article (10) appears to be available only in criminal cases. } \\
\text { - Right of free legal aid is not provided for family or civil } \\
\text { cases }\end{array}$ \\
\hline $\begin{array}{l}\text { Article } 31 \text { : } \\
\text { Right to health }\end{array}$ & Right to health & $\begin{array}{l}\text { Primary health care rights recognized as fundamental rights } \\
\text { women's right, emergency health care rights ensured for } \\
\text { citizen and non-citizen }\end{array}$ \\
\hline
\end{tabular}

Source: Gender audit: Constitution of Nepal by I. Tuladhar, 2015.

Women and gender concerns appeared in all national development plans from 1980 onwards. However, gender equality and empowerment of women was adopted exclusively in the Ninth Five-year Plan (1998-2002). The Tenth Five-year Plan (2002-2007) recognized women right (women's empowerment, gender equality, formulation of a gender mainstreaming policy and adopting a GRB system) as a key indicator of poverty analysis. The Interim Plan 
(2007-2010) adopted a policy of engendering development through economic, social and political process to ensure inclusive development. The table 4 presents gender elements in national plans, 1980-2022:

Table 4: Gender Elements in National Plans (1980-2022)

\begin{tabular}{|c|c|c|}
\hline Period Plan & Plan Periods & Policy Approaches \\
\hline $6^{\text {th. }}$ Five-Year Plan & $1980-1985$ & $\begin{array}{l}\text { Adopted the policy of enhancing the efficiency of women and } \\
\text { recognizing the role of women in dev. }\end{array}$ \\
\hline $7^{\text {th. }}$ Five-Year Plan & $1985-1990$ & $\begin{array}{l}\text { Adopted the policy of enhancing efficiency and productivity } \\
\text { of women through a participatory approach. }\end{array}$ \\
\hline $8^{\text {th. }}$ Five-Year Plan & 1992-1997 & $\begin{array}{l}\text { Adopted the policy of ensuring equitable distribution of } \\
\text { development benefits by bringing women into the mainstream } \\
\text { of development. }\end{array}$ \\
\hline $\begin{array}{l}9^{\text {th. }} \text { and } 10^{\text {th. }} \text { Five- } \\
\text { Year Plans }\end{array}$ & $\begin{array}{l}1997-2002 \text { and } \\
2003-2008\end{array}$ & $\begin{array}{l}\text { Adopted the policy of mainstreaming gender, reducing gender } \\
\text { inequality and promoting the empowerment of women. }\end{array}$ \\
\hline $\begin{array}{l}11^{\text {th. }} \text { Three-Year } \\
\text { Plan }\end{array}$ & $2007-2009$ & $\begin{array}{l}\text { Identified the effectiveness and substantial differences in } \\
\text { gender equality and women's empowerment, involving } \\
\text { recognition, monitoring and valuation of women's work and } \\
\text { their roles in the economy }\end{array}$ \\
\hline Interim Plan & $2010-2012$ & $\begin{array}{l}\text { Provided basis for initiating gender sensitivity in budgeting } \\
\text { and implementation by establishing Women Development } \\
\text { Offices in all the districts along with programs and } \\
\text { establishment of monitoring mechanism for gender related } \\
\text { activities. }\end{array}$ \\
\hline $\begin{array}{l}13^{\text {th. }} \text { and } 14^{\text {th. }} \text { Three } \\
\text { Year Plans }\end{array}$ & $\begin{array}{l}2013-2015 \text { and } \\
2016-2018\end{array}$ & $\begin{array}{l}\text { Recognize improving gender equality and addressing issues of } \\
\text { "backward" regions, classes and communities and excluded } \\
\text { groups requires conscious efforts, for poverty reduction. }\end{array}$ \\
\hline $15^{\text {th. }}$ Plans & $2019-2024$ & $\begin{array}{l}\text { Establish conducive environment for livelihood for women } \\
\text { through institutionalizing the 'Gender Accountable' governing } \\
\text { system, and ensuring equitable access of women in resources, } \\
\text { opportunities and benefits for women leadership in economic } \\
\text { development of the country. }\end{array}$ \\
\hline
\end{tabular}

Source: Various Periodic Plans (National Planning Commission)

\section{Constraints of Women in Economics in Nepal}

When talking about the women in economics, it is concerned about the upliftment of women's position in the economic growth process with equitable distribution of resources and power. It is only possible when economic policies are effectively implemented, which is here termed as good economic policies. Other way round is bad policies. In this section, whether women's contribution in the process of economic growth has empowered them to have equal access to elements of women in economics (to resources, technology, opportunity, decision making and control of income) and whether it has improved their quality of life, has been examined. Challenges are derived analyzing the implementation status of the policies based on the findings of the two studies like - i) Effectiveness of Gender Responsive Budgeting (GRB) in Nepal, 2019; and ii) Women's Contribution in Family Economy in Nepal, 2010.

As in other countries, improving access to the elements women in economics has remained a big challenge. Government using gender budgeting as a tool for closing gender gaps is in line with the basic principles associated with a well-functioning budgetary process. Further, making gender responsiveness as mandatorily classification in the budget demands of all line ministries, 
departments, and project units is considered a milestone in gender sensitive budgeting system in Nepal. Allocation of more than NRs. 500 billion annually during the fiscal years 2018/19 to 2020/21 under budget directly benefiting women could be consider as a great opportunity (see table 1).

It is common practice all over the world that the government transfers budget judiciously based on the principle of necessity. It is done to make sure that those projects facing budget shortage are not disrupted. It is quite good to transfer unspent budget in the last two or three months of the conclusion of annual fiscal year based on necessity. The government assumes that budget allocates based on the currently development needs. The international practice is that the concerned agencies are subject to legal action if they fail to spend money as outlined in the budget. In Nepal, there are no specific laws to address this sort of fiscal behavior. Instead, it continues to flourish.

Analysis of effectiveness in implementing of the gender budget in five local governments of Kathmandu Valley indicated that there is usual practice of virement ${ }^{11}$ in budgeting system. This indicates that even the budget allocated for direct benefit for women are allocated in ad-hoc way without identifying the gender concerns and needs as indicated in GRB Guideline. It also indicates that the budget is allocated such heading where they cannot spend or don't want to spend it. Thus, the need of virement arise to spend the budget. Not only in the local governments, practice of virement in budgeting system is widely practiced in provincial and federal budgeting system, as it could be observed budget transferring process starts immediately after the final approval of the respective annual budget by provincial and federal parliaments. As long as virement system dominates the budgeting system, even the implementation of excellent policy will be able to deliver expected results.

Issue of GRB Formulation Guideline-2012, with indicator-based monitoring mechanism framework for gender sensitivity tried to clarify the ambiguity of what is directly, indirectly, or gender-neutral programmes and activities and provided objective-orientation in measuring the impact of budget on women empowerment. Unfortunately, the GRB Formulation Guideline2012 focused only on monitoring and measuring the impact. This has created confusion to the line ministry, line agencies and local government (Municipalities) and ignored the formulation part (difficult step) and started allocating budget without proper analysis of gender needs. The federal, provincial and local governments fail to address the crucial step-identifying strategy for gender need (specific needs of women and men) and build up its implementation strategy on the gender needs. This could be because of lack of adequate information (due to lack of practice maintaining gender disaggregated data) about execution of gender specific services, projects or benefits in order to address an identified gender inequality. This has encouraged a kind of adhoc system which did not guarantee the immediate benefit to the women in terms of income generation and employment creation as expected in GRB Formulation Guideline - 2012.

National Census - 2011 indicates that agriculture sector's contribution is 35 percent to gross domestic product (GDP). Nepal Labor Force Survey, 2017/18 reports that one in five people in Nepal are employed in agriculture, forestry and fishing. The survey claims that out of total working age population (1523 thousand population involved agriculture, forestry and fishing) are women (57.19 percent).

\footnotetext{
${ }^{11}$ 'Virement' is a technical budgetary term for transfer of budget allocation from one heading to another.
} 
Land is the most important means of production. Land holding is considered as access to capital. National Census - 2011 in Nepal suggests that out of 3,715,555 households with land ownership only 19.71 percent of the households are female-headed with land ownership. This indicates huge disparity between males and females in terms of access to capital. Though government of Nepal has enforced the policy and rule of exempting 25 percent of registration fee in case of purchasing the land under the ownership of women is assumed to be contributing in increasing access to property, in practice still men are purchasing lands in women's name without giving them full ownership or control of the asset, just to take advantage of the tax break. In practice, women are not in a position to sell the property themselves (Oxfam, 2019).

Workflow analysis of 41 indigenous economic activities of Kathmandu Valley indicates the women's contribution in these activities is 52.5 percent in an average. Analysis shows that women's contribution is higher in the activities like art (painting) works (80\%), thread / cotton dyeing and printing (75\%); metal casting and craft $(60 \%)$; agricultural work (paddy plantation $59 \%$ ) and so on (Rajkarnikar, 2010). Women's involvements are considered their traditional patterned of domestic economic activities. For example, in agriculture activities they are involved in land preparation, weeding, transplanting, harvesting, winnowing, processing and preservation activities that are considered women's work. Workflow also indicates that in majority of the economic activities usually men are involved in selling. Such income in the family are considered as family income and women have no control over it. As a result, women's lives have been negatively affected in terms of women in economics.

The positive impact of any economic growth can be gauged by the extent to which it reduces women's workload. 'Reduction in women's workload and quality of their time use' is one of the indicators of gender equality outlined in the Gender Responsive Budget (GRB) Formulation Guideline-2012. Nepal Labor Force Survey, 2017/18 provides following data regarding male and female's involvement in household chores as shown in given table 5.

Table 5: Male and Female Involvement in Household Chores

\begin{tabular}{|c|c|c|c|c|c|c|}
\hline \multirow{2}{*}{ Activities } & \multicolumn{3}{|c|}{ Involvements (no. in '000) } & \multicolumn{3}{|c|}{ Percent } \\
\hline & Male & Female & Total & Male & Female & Total \\
\hline $\begin{array}{l}\text { Cooking, Cleaning, Washing and } \\
\text { Minor maintenance }\end{array}$ & 3,549 & 10,228 & 13,777 & 25.76 & 74.24 & 100 \\
\hline $\begin{array}{l}\text { Help or Assistance provided to } \\
\text { elderly, ill or disabled family member }\end{array}$ & 198 & 382 & 580 & 34.14 & 65.86 & 100 \\
\hline $\begin{array}{l}\text { Looking after own or family's } \\
\text { children }\end{array}$ & 1,212 & 3,260 & 4,472 & 27.10 & 72.90 & 100 \\
\hline $\begin{array}{l}\text { At least one activity of providing a } \\
\text { service for final own use }\end{array}$ & 4,342 & 10,466 & 14,808 & 29.32 & 70.68 & 100 \\
\hline & & & Iverage & 29.08 & 70.92 & 100 \\
\hline
\end{tabular}

Source: Nepal Labor Force Survey, 2017/18.

Approximately 14.8 million of population aged 15 years and above were involved in at least one activity of providing services for own final use. The disparity between males and females is significant in that only 29.08 percent of males in this group were involved in household chores, while percent of females is 70.92 (CBS, 2019). 
Assessment of implementation of Women Development Programmes addressing gender equality in changing of traditional role (household Chores of women) in five local governments (municipalities) of Kathmandu Valley, all the municipalities agree that they failed to address special needs of women. They also claimed that Municipalities has worked out methodology for easing work performance and time saving for women including changing of traditional role of women in their women development programs, but impact of such programs are never monitored because of lack of mechanism (Rajkarnikar, 2019).

Women are deprived of the knowledge and skills required for the modernization of agriculture. For example, the respondents of the study of 41 indigenous economic activities opinioned that denial of technology to women is a universal phenomenon and that new technology goes to men and not to women when it is introduced. When weeding machines were introduced, those went to men despite the fact that women traditionally did weeding. Similarly, when tractors were introduced for threshing purposes, these too went to men despite the fact that women too were traditionally involved in threshing (Rajkarnikar, 2010). It is observed in the analysis of women development programs in five municipalities of Kathmandu Valley that women were offered programs organized around the concept of domesticity. The programs aimed at women were home gardening and training in sewing which were traditionally considered to be the woman's domain of work. These courses expected to make women better housewives rather than economic producers (Rajkarnikar, 2019). Even the vocational training provided by 'Enhanced Vocational Education and Training (EVENT)' in relation to what they do (production and agriculture) has not been given. Instead, they have been given training on areas which have no direct relevance to what they do. Training has been given on dressmaking and bee keeping which are traditionally considered women's domain of work. These services have emphasized domestication of women.

Access to decision making and control of income is another aspect of women in economics. Though women are invariably engaged in income generating activities in the economy, exclusion of women from the decision-making process with regard to production, credit, marketing and technology is common phenomenon in the developing countries. Women and girls in Nepal have improved access to education, reflected in educational and professional outcomes. Moreover, any act of discrimination based on sex, pregnancy, or marital status has been criminalized, and traditional harmful practices have been made punishable. Affirmative action laws and policies have improved women's voice in the affairs of politics and governance. Still deeply embedded patriarchal norms, customary practices and common beliefs are contributing to creating combined adverse-effects on women's decision making and control of income.

There is a wide belief that the family income is considered as the income made by the male member. Workflow analysis of 41 indigenous economic analysis clearly indicates males are involved in money matters (selling) of the economic activities, and income is considered family income. Even women's contribution for happening the income is 80 percent, family head (usually male) decides on spending the income earned. Women have no control over the income (Rajkarnikar, 2010).

Aside from the political lives, women are being discriminated in the field of economy. Wage inequality between sexes for equal work still prevails. Despite the engagement in the process of accelerating the economy, Nepali women are not economically empowered. 
Domestic works are not quantified. Consequently, though country has been ranked high in terms of women's labour force participation, but not in other aspects of economic equality.

Women's participation in number in the political domain is considered a strong indicator of women's empowerment in Nepal. But, the study result of GRB Effectiveness Self-Assessment in five municipalities of Kathmandu Valley indicates weak participation of women in formulation and implementation of programs in municipalities. GRB guideline expects women participation in meeting, discussions, follow-up and monitoring of the budget implementation be made mandatory. Under-representation and passive participation of women in such activities is observed in the municipalities. This indicates that capabilities of the existing human resource are a big challenge. It could be the indications of lack of proper understanding of gender concept and political commitment for women's participation and gender development. Besides, it also needs capacity of the women representatives to understand why gender budget is allocated and capacity to take right decision (Rajkarnikar, 2019).

\section{Way Forward for Fostering Women in Economics in Nepal}

As mentioned earlier, sustainable economic development is possible only if the women are capable to utilize the resources; capable to control and reap the benefits of economic opportunities; and capable to make strategic decision for changing their lives positively, once they have accesses to resources. Once women are capable, there would be no limitation to be involved in economics. As GRB guidelines, major focus is capacity building of women to participate in economic growth. The first step in this endeavor would be to re-formulate 'GRB Formulation Guideline' so as to elaborate each step (process) of GRB formulation in a simple way. Analysis of gender situation and identification of gender concerns, needs should be made mandatory. Gender budget allocation should be accompanied by identified gender needs and program and strategy for its accomplishments. Result Based Budgeting (RBB) system has proven to be a compatible framework for the institutionalization of gender budgeting with three central elements of a sound performance management system and SMART indicators:

\section{Elements:}

- Objectives - Clearly articulated and measurable

- Programs - Structured and costed

- Key Performance Indicators - Focused on outputs and outcomes, are SMART and meaningful and support decision making

\section{SMART Indicators:}

- Specific - Target a specific area for improvement

- Measurable - Verifiable

- Assignable - Specify who will do it

- Realistic - Results that can be achieved realistically, given available resources

- Time-related - Specify when the result(s) can be achieved

The Financial Procedures Rule - 2007 of Nepal, has clearly spelled out while making 'budget transfer from one expenditure heading to another expenditure heading under any subhead should be made without cutting down the annual program or causing obstruction to the annual program and altering the source'. The second step would be to put restrictions in unnecessary budget transfer the budgeting software itself. 
Nepal has reached the digital age in budget formulation process. Line Ministry Budget Information System (LMBIS); Provincial Line Ministry Budget Information System (PLMBIS); and Sub-national Treasury Regulatory Application (SUTRA) are being used as budget formulation software for federal, provincial and local governments. It should not be difficult to restrict, on the one hand ad-hoc (lump-sum) budget allocation without accompanying identified gender needs and program and strategy, and on the other hand, unnecessarily transferring of budget through digital system breaking the government's financial procedures rule. This would create positive impact of the gender budgeting system and best utilization of NRs. 500 billion annually in gender equality (capacity building).

Capacity building here could be referred to the investment in human capital, which is an important factor for economic development. The World Bank Human Capital Project had provided three basic indicators for measuring human capital status of the country that is termed as Human Capital Index (HCI) - they are the contribution of nutrition (for survival); health (functional health); and education (educational attainment, education quality) to the productivity of the next generation of workers. It provides the status of country's complete education and full health to provide direction for improvement (for country's prosperity). Investment in education and health supplemented by nutrition for girls would have a catalytic effect on every dimension of development: lower child and maternal mortality rates; increased educational attainment by daughters and sons; higher productivity; and improved environmental management. Together, these can mean faster economic growth, and equally important, wider distribution of the fruits of growth. More education for girls will also enable more and more women to attain leadership positions at all levels of society: from health clinics in the villages to parliaments in the capitals. This, in turn, will change the way societies will deal with problems and raise the quality of global decision-making.

\section{Conclusion}

Economic growth means that most citizens live better life across all dimensions of material life. Women in economics are a prerequisite for sustainable development. However, i) access to resources and capacity to utilize it; ii) access to economic opportunities and control over the economic benefits of those opportunities; and iii) access to strategic choices leading to positive changes in their lives are the conditions necessary for women to be in economics.

Though Nepal is predominantly patriarchal society, roles of women have changed in various ways. As a response to the commitments made in various national and international gender equality and women-centric conventions and treaties, MoF of Nepal has introduced 'Gender Budgeting System' in the fiscal year FY 2007/08 which has categorized national budget under three broad headings: i) Budget directly benefiting women; ii) Indirectly benefiting women: and iii) Neutral budget. Government of Nepal allocated 38.65 percent. More than NRs. 500 billion of the total budgets in the programmes directly benefitting women for the FY 2020/21. Gender Responsive Budget (GRB) Formulation Guideline, issued in 2012 aimed at providing a guide in implementing gender budgeting system by making national budget and programs more gender responsive and evaluating the achievements.

In Nepal, budget transfer is common practice which is negatively affecting the output of gender budgeting system. Besides, the GRB Formulation Guideline - 2012 which is only on monitoring and measuring the impact instead of guiding the GRB Formulation has encouraged allocating budget without proper analysis of gender needs. This has encouraged a kind of ad-hoc 
system which did not guarantee the immediate benefit to the women in terms of income generation and employment creation as expected. Re-formulation of the GRB Guideline to elaborated each steps (process) GRB formulation in a simple way, and restriction of the unnecessary virement process would be crucial to create positive impact of the gender budgeting system and best utilize the NRs. 500 billion annually in gender equality (capacity building) for economic growth. As of the spirit of GRB Guideline, investment in human capital might be able to change the way society deals with problems and raise the quality of global decision-making.

\section{References}

Boserup, E. (1970). Woman's role in economic development. Journal of Agriculture Economics, Agriculture and Applied Economic Association, vol. 53(3), pages 536-537.

CBS (Central Bureau of Statistics) (2019). Report on the Nepal Labour Force Survey- 2017/18. Central Bureau of Statistics, Nepal. http://www.cbs.gov.np

Duflo, E. (2012). Women empowerment and economic development. Journal of Economic Literature 2012, 50(4), 1051-1079 http://dx.doi.org/10.1257/jel.50.4.1051.

DeLong, J. B. (2002). Theory of economic growth. Department of Economics, 601 Evans Hall University of California, Berkeley.

GoI (Government of India) (2015). Gender Budgeting. Handbook for Government of India. Ministry of Women and Child Development, (GOI) India.

MoF (Ministry of Finance) (2008 -2020). Budget Speeches (2008 - 2020). Ministry of Finance, Government of Nepal, Singha Darbar, Kathmandu.

MoF (Ministry of Finance). (2012). Gender Responsive Budgeting Guideline - 2012. Ministry of Finance, Singha Durbar, Kathmandu. Singha Darbar, Kathmandu.

NPC (National Planning Commission) (1980 -2019). Periodic Plans (1980/81 - 2019/20). National Planning Commission, Government of Nepal, Singh Durbar, Kathmandu.

Oxfam (2019). Promoting women's economic leadership in Nepal. Oxfam Country Office, Jawalakhel, Lalitpur, Nepal. http://www.nepal.oxfam.org

Rajkarnikar, R. S. (2010). Women's contribution in family economy in Nepal. A thesis submitted to Central Department of Buddhist Studies as requirement under M.A. in Buddhist Studies, Tribhuvan University. http://www.dr-reshmee.com

Rajkarnikar, R. S. (2019). Effectiveness of gender responsive budgeting in Nepal. A research report submitted to University of Grant Commission (UGC), Research Division, Sano Thimi. http://www.dr-reshmee.com

Tuladhar, I. (2015). Gender audit: Constitution of Nepal. Paper presented in Royal Norwegian Embassy, Lalitpur, Program organized by Institute for Democracy and Electoral Assistance, Nov. 26, 2015.

United Nations (2005). Progress Towards the Millennium Development Goals, 1990-2005. SecretaryGeneral's Millennium Development Goals Report. New York and Geneva: United Nation 